\title{
Nasse Mitte
}

\section{Die Seite für Kinder}

\section{Brigitte Lutz-Westphal}

In einem Waschbecken mit geradem Boden oder einer Badewanne kannst du etwas beobachten: Lasse Wasser aus dem Wasserhahn und gleichzeitig aus einem Gefäß (zum Beispiel einer Gießkanne) so hineinlaufen, dass zwischen den beiden Wasserstrahlen eine dünne Wasserwand entsteht.

Wann klappt das, wann nicht? Kannst du dir erklären, warum das so passiert? Die Wasserwand beschreibt einen „geometrischen Ort", also die „Menge aller Punkte, die ..." eine gewisse Eigenschaft haben. Findest du heraus, welche das ist?

Was passiert, wenn du mit der Hilfe einer anderen Person drei oder mehr solche Wasserstrahlen erzeugen kannst?

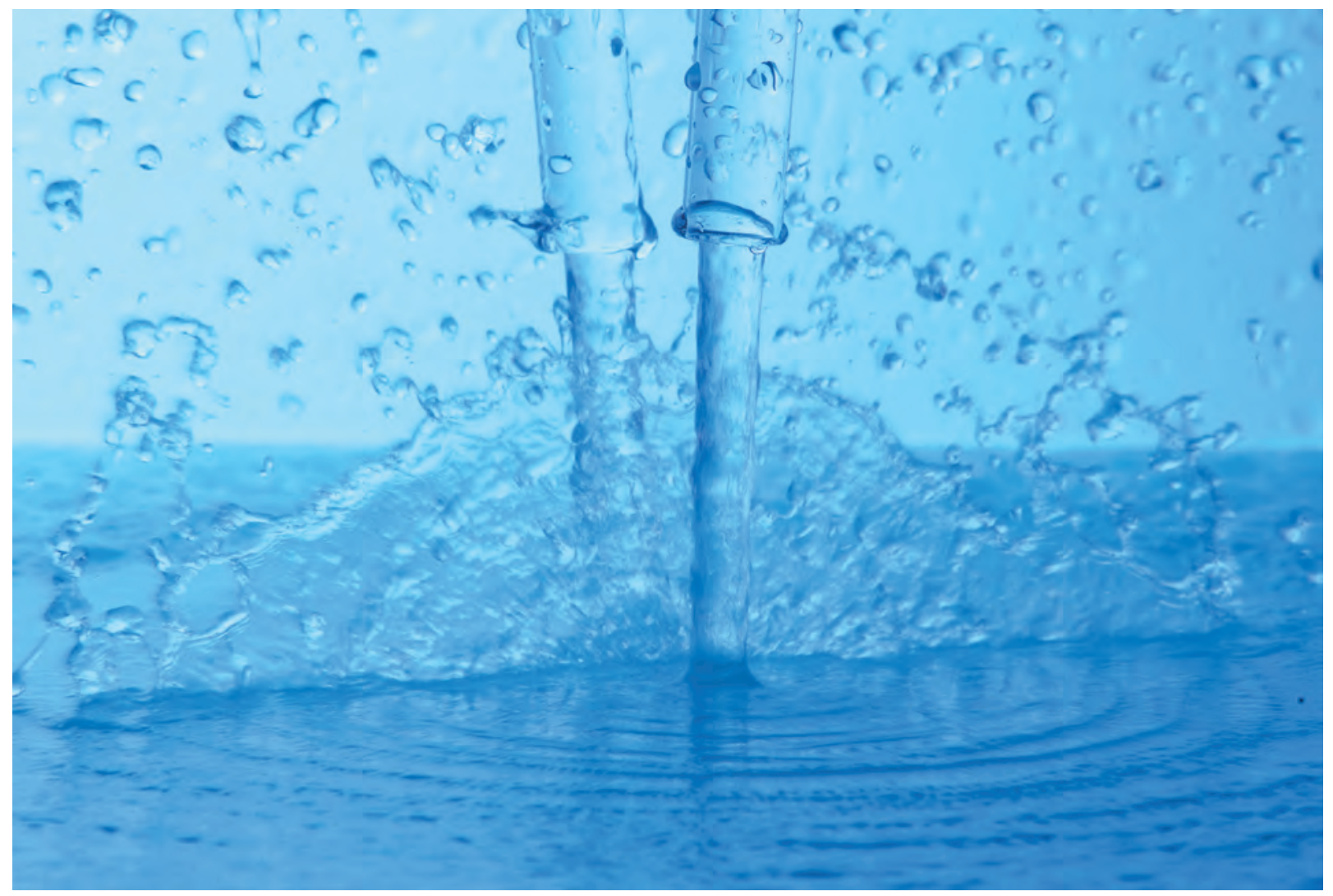

Prof. Dr. Brigitte Lutz-Westphal, 